\title{
Nigeria's Public External Debt and Economic Growth: Reconsidering the Empirics
}

\author{
Nora Inyang, Ubong Effiong
}

\begin{abstract}
This study examined the influence of external debt on the economic growth of Nigeria using annual time series that span through the period 1981 to 2019 . The study employed the Augmented Dickey-Fuller test for unit root; ARDL Bounds test for cointegration; and the error correction model (ECM) to tie the short-run equilibrium to the long-run. The unit root test revealed that the variables were stationary in mixed order of integration necessitating the use of the ARDL Bounds test for cointegration. The ARDL Bounds test revealed that there is a long-run relationship between economic growth and the explanatory variables in the model. In the ECM, the effect of the external debt was disaggregated into debt burden, debt overhang, and debt crowding out effect. From the findings, debt burden posed a positive but insignificant effect on economic growth implying that external debt can be growth inducing. However, debt overhang and debt crowding out effect exerted a negative and significant effect on economic growth. From the Error Correction Model, $72.4 \%$ of the short-run disequilibrium is corrected annually to return the model back to equilibrium in the long-run. Model had a high goodness of fit whereby the explanatory variables explained $87.50 \%$ of the total variations in economic growth. The paper recommended that there is need to gear external debt to sound investments outlets to avoid the negative effects that misappropriation of such resources can pose.
\end{abstract}

Index Terms - Debt Servicing, Crowding Out Effect, Debt Overhang, Debt Burden.

\section{INTRODUCTION}

Highlight External debt, the necessary evil in some situations, has remained an issue of concern in developing countries such as Nigeria. The quest for obtaining external debt has been based on the premises of financing fiscal deficits and achieving economic growth since developing countries in their early stages of development need to borrow externally because of inadequate domestic capital for investment [1]. Thus, external debt is obtained to bridge the gap between government revenue and expenditure programmes in the context of inadequate capital. Hence, external debt constitutes a significant proportion of public debt structure in developing countries [2]. In the case of financial stability in the domestic economy, excessive domestic borrowing can lead to financial instability and crowd out the private sector [3] creating an imperative for reliance on external debt.

From the foregoing, nations of the world are moved to borrow externally when there is a shortfall of savings that can be utilized to finance productive investments [4]. Though external debt can be utilized to finance such investments, it comes with an opportunity cost. This made [5] to posit that accumulation of substantial debt by a nation creates the room for a reasonable proportion of public expenditure and foreign exchange earnings to be absorbed into debt servicing and repayment with heavy opportunity costs. This scenario in the literature has been described as 'debt crowding out effect'. Thus, excessive external debt constitutes obstacle to sustainable economic growth and poverty reduction [6].

Meanwhile, public external debt exerts other effects on the economy. One of such is the debt overhang - a situation in which the expected repayment of foreign loan falls short of the contractual value of the debt due to debt servicing. The debtor country will expect an increase in the tax rate on returns to capital to service the debt, which in turn reduce their investment levels to avoid higher future tax [7]. The key aspect of the external has been measured in terms of debt burden - measured as the ratio of external debt to GDP. This measure captures how much of our total output goes into settling debt. The higher the percentage, the higher the debt burden and vice versa.

External debt can influence the economy of a nation either positively or negatively. The negative effect of debt is captured by the debt burden, the debt overhang and debt crowding out effect. This negative relationship between external debt and economic growth is related to researches such as [8], [9], and [10]. However, the positive effect of external debt on economic growth has been built on the premises that even if external debt is inconsequential in the savings and investment function, it can still influence output growth through its effects on factor productivity and growth mix [11]. It therefore becomes pertinent that we strike a balance in the volume of external debt accumulated. This is because there is an optimal level of debt that can throttle growth, beyond which leads to economic retardation [12]. The debt burden of Nigeria has been rising sharply in the 1980s to 1994 and thereafter declined sharply from 1994 to 2006 and has been maintaining a steady movement over the period 2006 to 2019. A snapshot of this is presented in Figure 1. 


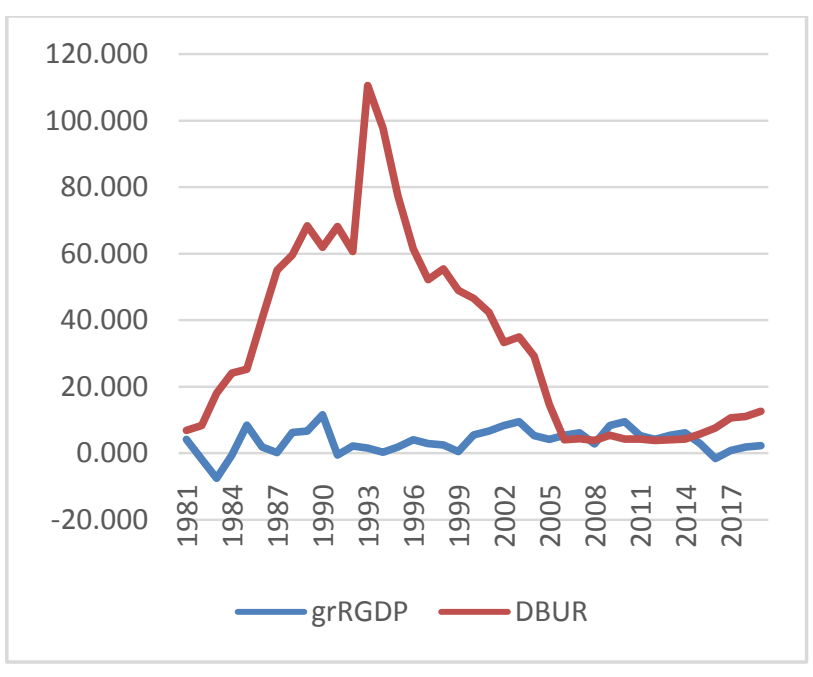

\section{Figure 1: External Debt Burden (DBUR) and Real GDP Growth Rate in Nigeria}

Nigeria's volume of external debt outstanding has been increasing over the years. As at 1981, the volume of external debt outstanding was N2.33 billion and rose to N100.79 billion as at 1987 and averaged N28.01 billion over the reference period. Similarly, external debt outstanding stood at N298.61 billion in 1990 maintaining a record high of N633.02 billion as at 1998 [13]. The period 1999 to 2005 witnessed a significant increase in the volume of domestic debt outstanding in Nigeria where it averaged N3,549.66 billion within the period. However, the period 2006 to 2011 witnessed a sudden decline with an average external debt outstanding of N598.46 billion. A reverse of the trend was observed between 2012 to 2019 where the average external debt outstanding rose to $\mathrm{N} 4,025.66$ billion.

Despite this upsurge in external debt accumulation and related servicing cost, Nigeria government, under the leadership of President Buhari, is still striving towards striking a loan deal with China. A total of $\$ 22.7$ billion loan request have been approved by the Senate and it is assumed that Nigeria could service the loan till 2040 [14]. This loan is reported to be used in financing infrastructural development, especially in the rail transport system. This loan is expected to come from diverse sources such as China EXIM Bank, World Bank, African Development Bank (ADB), Islamic Development Bank (IDB), Japan International Cooperation Agency (JICA), German Development Bank (GDB), and French Development Agency (FDA). Of all these sources, about 70\% (\$17,065,496,773) of the $\$ 22.7$ billion loan bid will be coming from China's EXIM Bank which is the largest bilateral lender in nearly two decades. This is not the only loan that Nigeria has obtained since it has been reported that Nigeria had borrowed $\$ 6.5$ billion from China since 2002 [14].

This rising trend in external borrowing over the years and the present quest for more loans raises issues of concerns from policy makers and concern citizens as to the usefulness of such loans and the attendant servicing cost that Nigeria will likely encounter. This study therefore seeks to investigate the influence of external debt on the economic growth of Nigeria. Several studies have been conducted to ascertain the effect of external debt on economic growth. Such include [15];[16];
[2]; [17]; [18][19][20][21][22][23][24][25] and [12]. This study is deemed necessary because it is coming up in a period in which the country is making an attempt to secure a great quantum of foreign loan. The study therefore seeks to allay the fears of the people on the extent to which debt can help Nigeria come out of her economic quagmire, post Covid-19. Such fears stem from the inability of the present generation to service the borrowed fund which may eventually be transferred to the future generation as a debt burden.

\section{LITERATURE REVIEW}

\section{Theoretical Literature}

The Harrod-Domar growth model stress the importance of savings and investment on growth. Thus, the theory states that the rate of growth of GDP is defined jointly by the net national savings ratio and the national capital-output ratio [1]. This therefore imply that savings must be matched with investment. The major issue is: how do countries invest when they do not have sufficient savings? This has made [26] to posit that the fundamental reason why developing and emerging countries amass external debt is lack of saving and investment. [27] submitted that the reasons why government borrow include when expected government revenue fall short of expected expenditure and there is need to pay off maturing government debt. Going back to the Harrod-Domar growth model, such borrowing can be regarded as capital accumulation which can fast track economic growth of a nation [28].

Several channels through which external debt could affect economic growth have been identified in the literature. Such include the Debt Overhang Hypothesis (DOH), Crowding-Out Effect of External Debt, Liquidity Constraint Hypothesis (LCI), Direct Effect of Debt Hypothesis (DEDH), and the Debt Laffer Curve. Debt Overhang, the Crowding Out Effect and Liquidity Constraint Hypotheses, suggest an indirect negative effect of external debt on economic growth through reductions in investment levels while Direct Effect of Debt Hypothesis (DEDH), is of the opinion that external debt can still influence growth through debt effects on factor productivity and investment [15]. However, the Debt Laffer curve presents a non-linearity in the debt-growth relationship.

The DOH is associated with [8] where he defined debt overhang as a situation in which the expected repayment of foreign loan falls short of the contractual value of the debt. Thus, the debtor country benefits very little from the return to any additional investment due to debt service obligations [29]. Thus, debt overhang is presented when a country's debt accumulation is greater than its strength and capacity of repayment in the future. Debt overhang is viewed based on two perspectives - traditional (narrow) and broader views. The traditional perspective is of the view that debt overhang effects exist when investors expect an increase in the tax rate on returns to capital to service the debt, and consequently reduce their investment levels to avoid higher future tax [7]. The imposition of such taxes for interest payments reduces individual's disposable income leading to reduction in the savings of the tax payers [15] 
. Based on the broader perspective, the argument is that there is disincentive to invest when investors expect inflation, devaluation and other economic distortionary measures as means to service the debt.

On the crowding out effect of external debt, debt service burden reduces public spending on social services which are drivers for growth. Heavy burden implies that the invisible hand short term revenue must be used to service the debt, thus crowding out public investment into the economy [9]. Due to the fact that private investment and public investment are complementary, such reductions leads to decrease in private investment as well [10].

The liquidity constraint hypothesis ( $\mathrm{LCH}$ ) captures the growth effect of a very high debt burden through the balance of payments account. This hypothesis is also regarded as the import compression effect, and is of the view that countries with high debt burden require enough inflow of foreign exchange so as to service the debt. The special requirement for this scenario is when the nation's currency is not tradable in the international market [15]. A country may resort to devaluation, import substitution, or export promotion to attract forex inflow when debt servicing becomes problematic as a result of low exports and capital inflow as well as inadequate reserves [9]. Thus, import compression can emanate leading to poor growth as a result of hike in the prices of essential imported commodities such as inputs and capital goods ([10], [15]).

The direct effect of debt hypothesis (DEDH) was hypothesized by [11] and stresses the positive influence of external debt on growth. Based on this hypothesis, even if external debt is inconsequential in the savings and investment function, it can still influence output growth through its effects on factor productivity and growth mix ([11] cited in [15]). Though it is reported by the debt overhang, the crowding out effect and liquidity constraint hypotheses that external debt can drag investments, [30] pointed out that it may also asphyxiate the productivity of the factors of production leading to growth.

The Debt Laffer Curve theory is associated with [12] and attributes a nonlinear relationship between external debt and growth. To him, there is an optimal level of debt that can throttle growth, beyond which leads to economic retardation. The Debt Laffer Curve represent the relationship between the face value of debt and investment, since the curve explains that as the outstanding debt increases beyond a certain threshold, repayment capacity begins to fall [15]. Thus, borrowing beyond such threshold leads to debt overhang and debt service challenges which may retard growth [31].

From the foregoing, we can therefore split the effect of external debt on economic growth into debt burden, debt overhang, and debt crowding out effect. These effects will be incorporated in our model for the analysis.

\section{Empirical Literature}

Inasmuch as the theoretical literature is fraught with mixed effect of external debt on economic growth, the empirical literature is not left out. [16] investigated the channels through which external debt affects growth. The study was conducted using panel data for the period 1996 - 1998 that span across 61 developing countries. The result showed that negative impact of high debt on growth operates through a strong negative effect on physical capital accumulation and on total factor productive growth.

[2] examined the impact of domestic and external debt on the economic growth of Pakistan separately over a period of 1980 - 2010 using ordinary Least Square approach (OLS) and co-integration analysis. From their findings, there is a significant negative effect of domestic and external debt on economic growth.

[17] examined the impact of debt burden on the Nigerian economy using time series data from 1970 - 2007. The Ordinary least square (OLS) method of estimation was used as the technique of analysis. The result showed a negative relationship between debt stock of internal and external; and gross domestic product, meaning that an increase in debt stock will lead to a reduction on the growth rate of Nigerian economy.

[18] examined the effect of external debt on the economic growth of Nigeria using time series data for the period 1970 2010. Data was analysed using econometric technique of ordinary least square. Findings of the study showed that external debt has contributed positively to Nigeria economy. [19] investigated the impact of external debt an economic of growth in Tanzania using time series of $1990-2010$. Findings of the study indicated that there is significant impact of external debt and debt service on GDP growth. The study reported a positive effect of debt stock on growth but asserted that debt service payment has a negative effect on growth.

The study by [20] over the period 1970 - 2010 revealed that there is a negative impact of external debt on economic growth in Latin America.

[32] utilized time series data for the period 1975 - 2003 to study the effect of external debt on economic growth of Malawi. They also observed a negative but statistically insignificant relationship between economic growth and foreign debt. They suggested that the government should provide more incentives to local producers to help them compete in the local and the international markets rather than relying on borrowing to expand their economy.

[33] investigated the impact of external debt on economic growth in Nigeria using time series data that ranges between 1980 to 2013. The study employed the Cointegration and Error Correction Model. The study revealed that external debt had a positive relationship with Gross Domestic Product at short run, but a negative relationship at long-run. Also, a negative relationship was reported to exist between External Debt Service Payment and Gross Domestic Product. It was recommended that Debt Management Office should set mechanism in motion to ensure that loans were utilized for purposes for which they were acquired as well as set a ceiling for borrowing for states and federal governments based on well-defined criteria.

A recent study by [15] was an attempt to examine the effect of external debt on economic growth in 39 Sub-Saharan Africa (SSA) using the Generalized Methods of Moments (GMM) approach. The study discovered that external debt negatively affects economic growth in SSA and that this is not affected by the categorization of countries into different per capita income levels. The study recommended that SSA countries should ensure that the foreign loans are invested in projects that would eventually generate enough returns to amortize the debt. 
In the same vein, [34] investigated the effect of external debt on the economic growth of Nigeria using time series data spanning between 1981 to 2017. The study employed the Granger Causality and Error Correction Mechanism. It was observed that external debt stock positive and significant effect on economic growth in Nigeria, whereas external debt service cost is not significant in explaining economic growth. Also, [35] examined the relationship between government external borrowing and economic growth in Oman for the period 1990 to 2015 utilizing the ARDL Cointegration approach. Findings of the study revealed a negative and significant influence of external debt on economic growth in Oman, and thus recommended a more productive use of the external debt fund in order to affect positive growth.

Other empirical studies which have supported the negative effect of external debt on economic growth are: [21] in sub-Saharan African countries; [22] and [36] for Pakistan; [37], [38], [39] and [40] for Nigeria; [41] for 114 developing countries. Others are [42]; [43]; [44]; [45]; [46]; [30]; [47]; and [23]. Also, studies like [48] and [49] reported a positive effect of external debt on economic growth while [50]; [24]; [25]; and [12] all reported that there is no correlation between external debt and economic growth.

Going by the above, it can be observed that the negative effect of external debt gain dominance in the literature and can therefore be upheld. This study will therefore try to strike a balance in detecting whether the debt burden, debt overhang, or debt crowing out effect that truly affects economic growth in Nigeria.

\section{METHODOLOGY}

This study employs an econometric approach and time series data for the period 1981 to 2019 were utilized. The data were obtained from Central Bank of Nigeria Statistical Bulletin and World Development Indicators.

To examine the effect of external debt on economic growth of Nigeria, the model for the study was formulated by adopting the model of [35]. The model is specified as follows:

GRRGDP $=\mathrm{f}(\mathrm{kGDP}$, LABR, EXTD, INFR, EXCR, TROP) - - - - (1)

Where:

GRRGDP $=$ Growth rate of real gross domestic product (a proxy for economic growth)

$\mathrm{kGDP}=$ Total investment as a percentage of GDP (a proxy for capital)

LABR $=$ Labour force growth rate (a proxy for labour)

$\mathrm{EXTD}=$ External debt

INFR = Inflation rate

$\mathrm{EXCR}=$ Exchange rate

TROP $=$ Trade openness (a ratio of trade to GDP)

Disaggregating the various effects of external debt - debt burden, debt overhang, and debt crowding out - in Equation (1) and transforming it into an econometric form, Equation (1) becomes:

GRRGDP $=\pi_{0}+\pi_{1} \mathrm{kGDP}+\pi_{2} \mathrm{LABR}+\pi_{3} \mathrm{DBUR}+$ $\pi_{4} \mathrm{DOVE}+\pi_{5} \mathrm{DCRO}+\pi_{6} \mathrm{INFR}+\pi_{7} \mathrm{EXCR}+\pi_{8} \mathrm{TROP}+\mu-$ $-\quad-(2)$

\section{Where:}

$\pi_{0}=$ constant, the intercept of the regression function $\pi_{1}$ to $\pi_{8}=$ the parameters to be estimated

DBUR = Debt burden, measured as external debt as percentage of GDP

DOVE $=$ Debt overhang, measured as a ratio total debt to gross national income (GNI)

DCRO = Debt crowding out effect, measured as total debt service as a ratio of export

$\mu=$ random error term which is assumed to be normally distributed.

In accordance to economic theory, it is expected that: (i) $\pi_{1}$, $\pi_{2}$, and $\pi_{8}$ are positive; (ii) $\pi_{3}$ can either be positive or negative; and (iii) $\pi_{4}, \pi_{5}, \pi_{6}$ and $\pi_{7}$ are negative.

Data were analysed using the Autoregressive Distributed Lag (ARDL) model and Error Correction Mechanism (ECM) to detect the effect of external debt on economic growth in Nigeria. The essence for using the ARDL approach is that the method avoids configuring a larger number of specifications in the standard cointegration test, and permits the use of different optimal lags for different variables. Meanwhile, a test for cointegration was conducted using the ARDL Bounds test by [51], [52], and [53] to detect the existence of a long-run (levels) relationship. The data were subjected to stationarity test using the Augmented Dickey-Fuller test technique since time series variables are sometimes influenced by time. The essence of the test was to eradicate an occurrence of a spurious regression result.

In line with [52], the ARDL approach to cointegration is specified as follows:

$\triangle G R R G D P_{t}=\pi_{0}+\sum_{i=1}^{P} \pi_{1} \Delta G R R G D P_{t-i}+$ $\sum_{i=0}^{P} \pi_{2} \Delta k G D P_{t-i}+\sum_{i=0}^{P} \pi_{3} \Delta L A B R_{t-i}+$

$\sum_{i=0}^{P} \pi_{4} \Delta D B U R_{t-i}+\sum_{i=0}^{P} \pi_{5} \Delta D O V E_{t-i}+$ $\sum_{i=0}^{P} \pi_{6} \Delta D C R O_{t-i}+\sum_{i=0}^{P} \pi_{7} \Delta I N F R_{t-i}+\sum_{i=0}^{P} \pi_{8} \Delta E X C R_{t-i}$ $+\sum_{i=0}^{P} \pi_{9} \Delta T R O P_{t-i}+\pi_{10} k G D P_{t-1}+\pi_{11} L A B R_{t-1}+$ $\pi_{12} D B U R_{t-1}+\pi_{13} D O V E_{t-1}+\pi_{14} D C R O_{t-1}+\pi_{15} I N F R_{t-1}$ $+\pi_{16} E X C R_{t-1}+\pi_{17} T R O P_{t-1}+\mathrm{V}_{\mathrm{t}}-$ -

Where $\Delta$ is first difference operator, $\mathrm{p}$ is the optimal lag length, and all other variables remain the same. The test for long-run relationship is conducted to detect whether there is a long-run relationship. If a long-run relationship exists, i.e. the variables are cointegrated, it implies that there is a long run (equilibrium) relationship which in turn implies that there is a short-run disequilibrium. Such short-run dynamics are obtained by estimating error correction mechanism as follows:

$\triangle G R R G D P_{t}=\pi_{0}+\sum_{i=1}^{P} \pi_{1} \Delta G R R G D P_{t-i}+$ $\sum_{i=0}^{P} \pi_{2} \Delta k G D P_{t-i}+\sum_{i=0}^{P} \pi_{3} \Delta L A B R_{t-i}+$

$\sum_{i=0}^{P} \pi_{4} \Delta D B U R_{t-i}+\sum_{i=0}^{P} \pi_{5} \Delta D O V E_{t-i}+$ $\sum_{i=0}^{P} \pi_{6} \Delta D C R O_{t-i}+\sum_{i=0}^{P} \pi_{7} \Delta I N F R_{t-i}+\sum_{i=0}^{P} \pi_{8} \Delta E X C R_{t-i}$ $+\sum_{i=0}^{P} \pi_{9} \Delta T R O P_{t-i}+\lambda E C M_{t-1}$ - - - - (4)

Where $E C M_{t-1}$ is the error correction mechanism defined by rearranging Equation 4 as:

$E C M_{t-1}=\Delta G R R G D P_{t}-\pi_{0}-\sum_{i=1}^{P} \pi_{1} \Delta G R R G D P_{t-i}$ $\sum_{i=0}^{P} \pi_{2} \Delta k G D P_{t-i}-\sum_{i=0}^{P} \pi_{3} \Delta L A B R_{t-i}-$

$\sum_{i=0}^{P} \pi_{4} \Delta D B U R_{t-i}-\sum_{i=0}^{P} \pi_{5} \Delta D O V E_{t-i}-$
$\sum_{i=0}^{P} \pi_{6} \Delta D C R O_{t-i}-\sum_{i=0}^{P} \pi_{7} \Delta I N F R_{t-i}-\sum_{i=0}^{P} \pi_{8} \Delta E X C R_{t-i}-$ 
$\sum_{i=0}^{P} \pi_{9} \Delta T R O P_{t-i}-$ - (5)

From Equation (4), $\lambda$ represents the speed of adjustment for the convergence of the coefficients of short-run equation.

\section{EMPIRICAL FINDINGS}

Based on the fact that we are dealing with time series variables, a test for stationarity therefore becomes imperative for us to determine the order of integration for each of the variables. This is presented in Table 1 and the result follows the constant assumption.

Table 1: Augmented Dickey-Fuller Unit Root Test Result

\begin{tabular}{l|ccccc} 
Variables & @Level & Probability & $\begin{array}{c}\text { @ First } \\
\text { Difference }\end{array}$ & Probability & $\begin{array}{c}\text { Order of } \\
\text { Integration }\end{array}$ \\
\hline GRRGDP & $-3.889 * *$ & 0.0049 & $-7.180^{* * *}$ & 0.0000 & $\mathrm{I}(0)$ \\
$k G D P$ & 1.182 & 0.9974 & $-8.114^{* * *}$ & 0.0000 & $\mathrm{I}(1)$ \\
LABR & -0.727 & 0.8278 & $-5.266^{* * *}$ & 0.0001 & $\mathrm{I}(1)$ \\
DBUR & -1.227 & 0.6519 & $-5.477 * * *$ & 0.0001 & $\mathrm{I}(1)$ \\
DOVE & -1.399 & 0.5717 & $-5.641^{* * *}$ & 0.0000 & $\mathrm{I}(1)$ \\
DCRO & -1.986 & 0.2914 & $-8.661 * * *$ & 0.0000 & $\mathrm{I}(1)$ \\
INFR & $-2.914 *$ & 0.0531 & $-5.680^{* * *}$ & 0.0000 & $\mathrm{I}(1)$ \\
EXCR & 1.400 & 0.9987 & $-4.259^{* * *}$ & 0.0018 & $\mathrm{I}(1)$ \\
TROP & -2.261 & 0.1893 & $-7.647 * * *$ & 0.0000 & $\mathrm{I}(1)$
\end{tabular}

Note: $*, * *$ and $* * *$ denote significance at $10 \%, 5 \%$ and $1 \%$ level respectively

Source: Authors' Computation using Eviews 10

Evidence from Table 1 indicates that the variables are stationary at mixed order of level $\mathrm{I}(0)$ and first difference I(1). All the variables are stationary at first difference except growth rate of real gross domestic product (GRRGDP) which

\section{Table 2: ARDL Bounds Test Result}

F-Bounds Test

\begin{tabular}{lcccr}
\hline \hline Test Statistic & Value & Significance & I $(0)$ & $\mathrm{I}(1)$ \\
\hline \hline F-statistic & 4.669 & $10 \%$ & 1.85 & 2.85 \\
$\mathrm{k}$ & 8 & $5 \%$ & 2.11 & 3.15 \\
& & $2.5 \%$ & 2.33 & 3.42 \\
& & $1 \%$ & 2.62 & 3.77 \\
\hline \hline
\end{tabular}

\section{Source: Authors' Computation using Eviews 10}

From Table 2, $\mathrm{k}$ denotes the number of parameters. The F-statistic (4.669) is greater than the $10 \%, 5 \%$, and even the $1 \%$ critical bounds value both at the upper I(1) and the lower $\mathrm{I}(0)$ bounds. The significance of the F-statistic is an

is stationary at level. This mixed order of integration makes it paramount for the adoption of the ARDL Bounds test for cointegration. The result is presented in Table 2.

\begin{tabular}{|c|c|c|c|c|c|}
\hline Variables & Coefficient & $\begin{array}{c}\text { Standard } \\
\text { Error }\end{array}$ & $t$-statistic & Probability & Decision \\
\hline$D(G R R G D P(-1))$ & $0.801 * * *$ & 0.144 & 5.572 & 0.0001 & Significant \\
\hline$D(k G D P)$ & $0.837 * *$ & 0.289 & 2.901 & 0.0133 & Significant \\
\hline$D(k G D P(-1))$ & $1.767 * * *$ & 0.306 & 5.782 & 0.0001 & Significant \\
\hline$D(L A B R)$ & -3.706 & 2.141 & -1.731 & 0.1091 & Not significant \\
\hline$D(D B U R)$ & 0.157 & 0.139 & 1.127 & 0.2817 & Not significant \\
\hline$D(D B U R(-1))$ & $-0.814 * * *$ & 0.151 & -5.381 & 0.0002 & Significant \\
\hline$D(D O V E)$ & $-0.204 * * *$ & 0.052 & -3.957 & 0.0019 & Significant \\
\hline$D(D O V E(-1))$ & $-0.390 * * *$ & 0.064 & -6.114 & 0.0001 & Significant \\
\hline$D(D C R O)$ & $-0.169^{*}$ & 0.083 & -2.034 & 0.0647 & Significant \\
\hline$D(D C R O(-1))$ & $-0.573 * * *$ & 0.081 & -7.054 & 0.0000 & Significant \\
\hline$D(I N F R)$ & $-0.116 * * *$ & 0.035 & -3.330 & 0.0060 & Significant \\
\hline$D(I N F R(-1))$ & $0.282 * * *$ & 0.032 & 8.765 & 0.0000 & Significant \\
\hline$D(E X C R)$ & -0.018 & 0.019 & -0.992 & 0.3409 & Not Significant \\
\hline$D(T R O P)$ & $0.604 * * *$ & 0.005 & 128.614 & 0.0049 & Significant \\
\hline$D(T R O P(-1))$ & $2.708 * * *$ & 0.018 & 148.728 & 0.0043 & Significant \\
\hline $\operatorname{ECM}(-1)$ & $-0.724 * * *$ & 0.113 & -9.040 & 0.0000 & Significant \\
\hline
\end{tabular}

$\operatorname{ECM}(-1)$ $-0.724 * * *$ relationship. We therefore estimate the short-run dynamics as follows 
Evidence from Table 3 indicates that all the variables except LABR and EXCR are not statistically significant. Since our core interest is on the effect of external debt on economic growth, special attention will be given to the three key variables namely; DBUR, DOVE, and DCRO. From Table 3, debt burden (DBUR) is not statistically significant in influencing economic growth in Nigeria. It also exerts a positive effect on economic growth. This is in line with the findings of [34], [48] and [49]. The idea behind the positive effect of debt burden on economic growth is adduced form the fact that borrowing to facilitate investment in productive aspect of the economy rather than for consumption or recurrent expenditure can be growth inductive. However, the one-period lag of debt burden, $\operatorname{D}(\operatorname{DBUR}(-1))$, exerts a negative and significant effect on economic growth. Thus, the past period of debt burden reduces economic growth by $0.814 \%$.

Interestingly, debt overhang (DOVE) and debt crowding out effect exert negative and significant effect on economic growth. Thus a unit percentage increase in debt overhang will lead to a $0.204 \%$ decrease in economic growth. Also, a unit percentage increase in debt crowding out will tantamount to a $0.169 \%$ decrease in economic growth. Meanwhile, the one period lag of debt overhang, $\mathrm{D}(\mathrm{DOVE}(-1))$, and debt crowding out effect, $\mathrm{D}(\mathrm{DCRO}(-1))$, will reduce economic growth by $0.390 \%$ and $0.573 \%$ respectively. The significance of the debt over hang and debt crowding out effect upheld the prevalence of the of the liquidity constraint hypothesis and debt overhang theory of Krugman (1989). The theory states that a rise in accumulated debt stock results in higher tax on future output and thus crowds out private investment and retards growth. The existence of the negative and significant effect of external debt on economic growth in Nigeria is in line with the findings of [21][38][37][22][41][36][20][40][33] [15] and [35].

Capital, measured as the ratio gross fixed capital formation to GDP, and trade openness - the ratio of trade to GDP - has positive and significant effect on economic growth in Nigeria implying that a $1 \%$ increase in capital and trade openness will result to a $0.837 \%$ and $0.604 \%$ increase in economic growth respectively. The positive and significant effect of capital on economic growth is also in line with the findings of [54] and [35] while the positive and significant effect of trade openness on economic growth is also in line with the findings of [15] and [35]. Capital is paramount in the production process and the stock of capital is also a major driver of growth based on the Solow growth model. Trade openness stems competition in the global market and therefore leads to accumulation of wealth hence, economic growth.

The variables in the model meet the a priori expectations as defined earlier. The R-squared (0.8750) presents a goodness of fit of the regression result. This implies that the explanatory variables explain $87.50 \%$ of the total variations in economic growth. The rate remains high $(79.76 \%)$ after being adjusted for the degree of freedom. The Durbin-Watson statistic (0.224), which is approximately 2, reveals the absence of serial correlation. Most importantly, the error correction term (ECM-1 = - 0.724) is rightly signed (negative) and statistically significant. This implies that $72.4 \%$ of the short-run disequilibrium is corrected annually to bring the model to a long-run equilibrium.

To investigate the stability of the short-run (dynamic) coefficients, the test for stability is conducted and the diagram is presented in Figure 2.

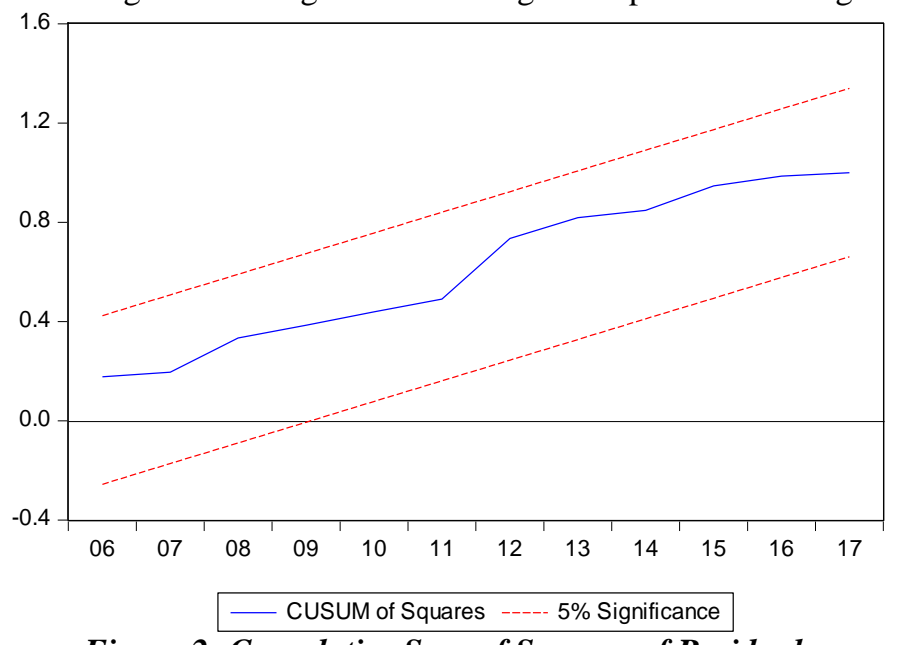

Figure 2: Cumulative Sum of Squares of Residuals

Since the CUSSUM of Squares line lies within the upper and lower bounds, the short-run coefficients are stable.

The model is also free from heteroscedasticity as the test leads to the rejection of the null hypothesis. The result is presented in Table 4.

Table 4: Heteroscedasticity Test Result

Heteroskedasticity Test: Breusch-Pagan-Godfrey

\begin{tabular}{lrlr}
\hline \hline F-statistic & 0.678 & Prob. F(22,12) & 0.7933 \\
Obs*R-squared & 19.390 & Prob. Chi-Square(22) & 0.6212 \\
Scaled explained SS & 3.325 & Prob. Chi-Square(22) & 1.0000 \\
\hline \hline
\end{tabular}

Source: Authors Computation using Eviews 10 
The F-statistic is not statistically significant hence, we conclude that the model is homoscedastic implying that the error terms possesses a constant variance.

\section{CONCLUSION AND RECOMMENDATION}

This study was an empirical investigation into the influence of external debt on economic growth in Nigeria for the period 1981 to 2019 . The study revealed a negative and significant effect of debt overhang, debt crowding out effect, and one-period lag of debt burden on economic growth in Nigeria. The explanatory variables in the model were able to explain $87.50 \%$ of the total variation in economic growth while $72.4 \%$ of the short-run disequilibrium was corrected annually. This is a powerful signal to policy makers that excessive procurement and management of external debt could make Nigeria suffer the negative relationship that exist between external debt and economic growth. Caution must be taken to maintain a healthy level of external debt and to utilize savings, investment, and external reserves so as to reap its benefits to the fullest.

Despite the negative relationship observed between external debt and economic growth in Nigeria, it should not be said that Nigeria should abruptly refused to borrow. This is due to the high savings gap in the country coupled with declining oil revenue. However, such loans and their utilization should be properly monitored and controlled by the Debt Management Office of the country. Such loans should be channelled to capital expenditures since such is growth inducing. This points to the fact that government should procure foreign loans to boost economic activities rather than political or social reasons. Loans limits should be set by the Debt Management Office to match with the hypothesis that there is an optimal level of debt that can throttle growth, beyond which leads to economic retardation. Also, corruption which is a salient factor that can lead to the diversion of foreign loans into selfish interest should be fought to the fullest and perpetrators officially brought to book.

\section{REFERENCES}

[1] P. M. Todaro and S. C. Smith,"Economic development", 11th edition, Washington D.C.: PearsonEducation, Harlow, 2011.

[2] R. Atique and K. Malik, "Impact of domestic and external debt on the economic growth of Pakistan",World Applied Sciences Journal, 20(1), 2012, pp. $120-129$.

[3] U.Panizza, F. Sturzenegger and J Zettelmeyer,"International government debt",UNCTADDiscussion Paper No. 199, Geneva, UNCTAD, June, 2010 http://EconPapers.repec.org/RePEc:wpbsdt:2010-03

[4] A. A. Momodu,"Effect of debt servicing on economic growth in Nigeria", 2010. reikojournals.org

[5] W.Albert, D. Brain and P.Palitha, "Economic growth and external debt servicing: A cointegration analysis of Sri Lanka 1952-2002", University of England School of Economics. Working Paper Series in $\begin{array}{llll}\text { Economics, } & 2005 . & \text { ISSN } & 14422980\end{array}$ http://www.une.au/feb1/econstud/wps.html.

[6] A. Manghyereh and U. Hashemite,"External debt and economic growth in Jordan: The threshold effect",Economina Internationale/International Economics 56(3), 2003, pp. 337-355.
[7] J. Sachs, "The debt overhang of developing countries". In Debt, Stabilization and Development: Essays in Memory of Carlos Díaz Alejandro, Oxford: BasilBlackwell, 1989, pp. 50-529.

[8] P. Krugman,"Financing vs. forgiving a debt overhang",Journal of development Economics, 29(3), 1988, pp. 253-268.

[9] J. Serieux and S. Yiagadeesen, "The debt service burden and growth: Evidence from low income countries", The North-South Institute, Ottawa, 2001. http://www.researchgate.net/

[10] L. Taylor,"Structuralist Macroeconomics: Applicable models for the Third World", New York: Basic Books, 1983.

[11] A. K. Fosu,"The impact of external debt on economic growth in sub-Saharan Africa”,Journal ofEconomic Development 21(1), 1996, pp. 93-117.

[12] D. Cohen, "Low investment and large LDC debt in the 1980s",American Economic Review, 83(3), 1993, pp. 437-449.

[13] Central Bank of Nigeria,"Statistical Bulletin”, 2019.

[14] Premium Times, "As Senate approves Buhari's \$22.7bn request, Nigeria could service Chinese loans till 2040", August 8, 2020.www.premiumtimesng.com

[15] B. Senadza, A. K. Fiagbe, and P. Quartey, "The effect of external debt on economic growth in Sub-Saharan Africa",International Journal of Business and Economic Sciences Applied Research (IJBESAR), 11(1),2018, pp. 61-69. http://dx.doi.org/10.25103/ijbesar.111.07

[16] C.Pattillo, H.Poirson, L. Ricci, A. Kraay and R. Rigobon,"Through what channels do external debt affect growth?"The Brooking $\begin{array}{llll}\text { TradeForum, } 2004, & \text { pp. }\end{array}$ http://www.grips.ac.jp/docu01/paper06

[17] S. Ogege and J. E.Ekpudu,"The Effect of debt burden on the Nigerian Economy”,Journal of Research in National Development 8(2), 2010.

[18] L. A. Sulaiman and B. A. Azeez,"The Effect of External Debt on Economic Growth of Nigeria",Journal of Economies and Sustainable Development, 3(8), 2012. www.iiste.org

[19] [19] F. Kasidi and A. M. Said, "Impact of external debt on economic growth: A case study of Tanzania",Advances in Management and Applied Economics, 3(4), 2013, pp. $59-82$.

[20] C.Calderón and J. R. Fuentes,"Government debt and economic growth”, Inter- American Development Bank, 2013.

[21] M. A. Iyoha, 'External Debt and Economic Growth in Sub-Saharan African Countries: An Econometric Study', Paper presented at AERC workshop in Nairobi, Kenya, March, 1999.

[22] N. Akram,"Impact of Public Debt on the economic growth of Pakistan”, The Pakistan Development Review, 2011, pp. 599-615.

[23] I. A.Elbadawi, J.Benno, C.Ndulu, and N. Njuguna,"Debt overhang and economic growth in Sub-Saharan Africa", in Zubair Iqbal and Ravi Kanbur (eds.), External finance for low-Income Countries (49-76), International Monetary Fund, 1996.

[24] P. C. Afxentiou and A. Serletis, "Growth and foreign indebtedness in developing countries: An empirical study using long term cross-country data",Journal of Development Economics 31(1), 1996, pp. $25-40$.

[25] K. Chowdhury, "A structural analysis of external debt and economic growth: Some evidence from selected countries in Asia and the Pacific",AppliedEconomics, 26, 1994,pp. 1121-1131.

[26] H. B.Chenery, and A. M.Strout,"Foreign assistance and economic development",The American Economic Review, 1966, pp. 679-733.

[27] J. O.Babu, S.Kiprop, A. M.Kalio, and M. Gisore, "Effect of domestic debt on economic growth in the East African community",American Journal of ResearchCommunication, 3(9),2015, pp. 73-95. 
[28] Eaton, “Sovereign debt: A primer",World Bank Economic Review, 7(3), 1993, pp. 137-172.

[29] E. Borensztein, "Debt overhang, credit rationing and investment", Journal of Development Economics, 32,2015, pp. 315-335.

[30] A. K.Fosu,"The external debt burden and economic growth in the 1980s: Evidence from Sub-Saharan Africa",Canadian Journal of DevelopmentStudies 20 (2), 1999, pp. 307-318.

[31] C. Pattillo, H. Poirson. and L. Ricci,"External debt and growth”,IMF Working Paper 02/69, 2002, pp. 1-47. http://www.imf.org/pubs/2002

[32] B. H. M. Tchereni, T. J. Sekhampuand R. F. Ndovi,"The impact of foreign debt on economic growth in Malawi",African Development Review, 25(1), 2013, pp. 85-90.

[33] U. S. Nwannebuike, U. J. Ike and O. I. Onuka,"External debt and economic growth: The Nigeria experience",European Journal of Accounting, Auditing and Finance Research, 4(2), 2016, pp. 33 - 48.

[34] A. C. Odubuasi, P. U. Uzoka and A. S. Anichebe,"External debt and economic growth in Nigeria",Journal of Accounting and Financial Management, 4(6), 2018.www.iiardpub.org

[35] [35] S. A. Kharusiand M. S. Mbah, External debt and economic growth: The case of emerging economy,Journal of Economic Integration, 33(1),2018, pp. 141-1157. http://dx.doi.org/10.11130/jei.2018.33.1.1141

[36] S. I. RaisandT. Anwar,"Public debt and economic growth in Pakistan: A time series analysis from 1972 to 2010 ",Academic research international, 2(1), 2012, p.535.

[37] J. Isu,"Nigeria's External Debt and Economic Growth: An Error Correction Approach",International Journal of Business and Management, 6(5), 2010, pp. 107-113.

[38] S. M. Chikuba,"The Impact of external debt on Zambia's economic growth", National Graduate Institute for Policy Studies, Lusaka, 2003.

[39] A. Umaru, A. A. Hamidu and S. Musa,"External debt and domestic debt impact on the growth of the Nigerian Economy",International Journal of Educational Research, 1(2), 2013, pp. 70-85.

[40] S. A. Mbah, O. C. Agu and G. Umunna,"Impact of external debt on economic growth in Nigeria: An ARDL Bound Testing Approach",Journal of Economics andSustainable Development, 7(10), 2016.

[41] A. F. Presbitero, "Total public debt and growth in developing countries", The European Journal of Development Research, 24(4), 2012, pp. 606-626.

[42] C. M. Reinhartand K. S. Rogoff, "Growth in a Time of Debt”,American Economic Review, 100 (2),2010, pp. 573-578.

[43] H. C. Butts, "Short term external debt and economic growth -Granger Causality: Evidence from Latin America and the Caribbean",The Review of Blackpolitical economy, 36, 2009,pp. 93-111.

[44] H. A. Hameed andM. A. Chaudhary,"External Debt and its Impact on Economic and Business Growth in Pakistan",International Research Journal ofFinance and Economics, 20, 2008, pp. 132-140.

[45] M. Were,"The impact of external debt on economic growth in Kenya: An empirical assessment",UNU-WIDER Research Paper, DP2001/116, 2001. http://www.wider.unu.edu/publication

[46] M. A. Iyoha,"External debt and economic growth in Sub-Saharan African countries: an econometric study",AERC Research Paper 90, Nairobi Kenya, 1999.

[47] A. Desphane, "The debt overhang and the disincentive to invest",Journal of DevelopmentEconomics, 52, pp. 169-187, 1997.

[48] T. K. Jayaraman and E. Lau,"Does external debt lead to economic growth in Pacific Island countries?'Journal of Policy Modelling, 31, 2008, pp.272-288.
[49] A. M. Warner, "Did the debt crisis cause the investment crisis?’Quarterly Journal of Economics, 107(4), 1992, pp. 1161-1186.

[50] M. Frimpong and E. F. Oteng-Abayie,"The impact of external debt on economic growth in Ghana: A cointegration analysis",Journal of Scienceand Technology, 26(3),2003, PP. 121-130.

[51] H. M. Pesaran and Y. Shin, “Autoregressive Distributed Lag Modelling Approach to Cointegration Analysis", DAE Working Paper Series No. 9514, Cambridge: Department of Applied Economics, University of Cambridge, 1995.

[52] H. M. Pesaran and Y. Shin,“Autoregressive distributed lag modelling approach to cointegration analysis",in S. Storm (Ed.) Econometrics and Economic Theory in the20th Century: The Ragnar Frisch Centennial Symposium, chapter 11, Cambridge: Cambridge University Press, 1999.

[53] H. M. Pesaran,"The role of economic theory in modelling the long-run”,Economic Journal, 107, 1997, Pp. 178-191.

[54] M. Safadari and M. A. Mehrizi,"External debt and Economic growth in Iran”,Journal of Economics and International Finance, Vol. 3, 2011 